\title{
Irigaray Between God and the Indians: Sexuate Difference, Decoloniality, and the Politics of Ontology
}

\section{Accepted version for Australian Feminist Law Journal Vol.43, No. 1}

\author{
Stephen D. Seely, Dept. of Women's \& Gender Studies, Rutgers University
}

In this essay, I situate Irigaray's philosophy of sexuate difference between the Heideggerian response to the collapse of the project of western modernity ("only a god can save us") and that of decolonial theorist Oscar Guardiola-Riviera ("only Indians can save our modern soul"). First, I return to Heidegger's theorization of "planetary technicity" as the ontology of modernity arguing, with Heidegger, that in order to respond to this problem we must return to the question of Being. From here, I link Heidegger's theory of technicity with the work of decolonial theory on the "coloniality of Being," suggesting that one reason for Heidegger's pessimism is that he did not think technicity from beyond a Eurocentric perspective. The recent "ontological turn" in decolonial anthropology that seeks to study indigenous thought as ontology, however, shows that there are resources for thinking beyond the onto-logic of technicity. Yet, here, I return to Irigaray's critique of Heidegger for his forgetting of sexuate difference in his analysis of technology to say that a move to a decolonial ontology beyond planetary technicity can only take place if we go through an ontology of sexual difference: because, as Irigaray shows, the onto-logic of technicity that underwrites coloniality and modernity begins in an ontological annihilation of life, sexuate difference, and the maternal debt, the only way to recover this is by thinking the question of sexuate difference. Finally, I conclude by examining the case of the Kogi peoples of Colombia who have warned westerners that the destruction of the planet can only be stopped if we learn to recompense our common Mother. This case, I suggest, shows how and why the turn to non-western ontologies as a way out of the death project of modern technicity must reckon with the work of Irigaray.

Stephen D. Seely is a doctoral candidate in Women's \& Gender Studies at Rutgers University. He works on questions of ontology, life, and sex in feminist, continental, and decolonial philosophy. He has published articles on affect theory, queer theory, sexual ethics, and ontology as well as a coauthored book with Drucilla Cornell, The Spirit of Revolution: Beyond the Dead Ends of Man. 


\section{IRIGARAY BETWEEN GOD AND THE INDIANS}

\section{SEXUATE DIFFERENCE, DECOLONIALITY, AND THE POLITICS OF ONTOLOGY} "There is no possible negotiation regarding life: life is or is not. The question is how can we cultivate what life is. As life
can never be treated as an object, our culture does not supply us with a method to answer this question."

-LUCE IRIGARAY ${ }^{1}$

1. Whither the Saving Power?

"Only a god can save us now," declared Martin Heidegger in 1966 as he entered the final decade of his life. ${ }^{2}$ As he saw it, the world had plunged into a nihilism that he identified with the "planetary domination" of technicity — the positioning of all that is as resources in a universal standing reserve to be ordered and arranged by technical-scientific rationality. This state of affairs, for Heidegger, is a direct result of the death of God in European modernity: the annihilation of the suprasensory realm of value that had structured western metaphysics since Plato had given way to a world that is entirely the product of a human will to power. Thus, Heidegger recognized that even our attempts to mitigate our own destruction—nuclear disarmament, development initiatives, environmental conservation efforts - were taking the form of an instrumental calculation and management that only further chain us to technicity as the constant fabrication of the world. While the death of the metaphysical God could have had a liberatory effect, it has instead conscripted us into a planetary network in which we are "posed, enjoined, and challenged by a power that becomes manifest in the essence of technicity." Only a god can save us, then, because only a god can restore us to a world

\footnotetext{
${ }^{1}$ Luce Irigaray and Michael Marder, Through Vegetal Being: Two Philosophical Perspectives (Columbia University Press 2016) 19.

${ }^{2}$ Martin Heidegger, “'Only a God Can Save Us": The Spiegel Interview' (trans William Richardson) in Thomas Sheehan (ed) Heidegger: The Man and the Thinker (Precedent Publishing 1981) 45 at 57 . In the case of all translated texts, translations have occasionally been modified in consultation with the original.

${ }^{3}$ As above at 58 .
} 
that is not entirely of our own possession and production, to the mystery of belonging to something that is out of our control, to forms of creative expression that reveal Being in new ways. For the late Heidegger, the only task left for thinking is to return to the question that western metaphysics never thought and that cannot be thought by technical-scientific rationality: the question of Being as irreducible to any being (even to God).

Given this, it certainly would have come as no surprise to Heidegger, who in 1939 had already defined the modern age as the age of the "conquest" of the world as the sum total of "man's representing productions," that our epoch would one day be designated as the Anthropocene. ${ }^{4}$ And although climate scientists have made it clear that we no longer have the luxury of time to poetize while awaiting the coming god, the fact that techno-scientific rationality appears to be the only possible way of thinking climate change should make us pause long enough to consider that perhaps Heidegger's message was not so far off base. Indeed, how else are we to understand the nowprevalent dictum that continental philosophy must adapt itself to the sciences if it is to have any relevance in the contemporary world except in terms of Heidegger's prediction of the impending 'dissolution of philosophy in the technologized sciences'? For Heidegger, this end of philosophy as the activity of questioning signals the triumph of planetary technicity, and because technicity emerges from western metaphysics, 'the end of philosophy means the beginning of the world civilization that is based upon Western European thinking. ${ }^{5}$ But if this triumph has not yet been as total as Heidegger imagined, then perhaps we can accept Heidegger's insight that planetary technicity represents the culmination and collapse of western metaphysics without accepting that only a god can save us. Perhaps, that is, there is a saving power in the thought of those who have somehow

\footnotetext{
${ }^{4}$ Martin Heidegger, "The Age of the World Picture" in Julian Young and Kenneth Haynes (ed and trans) Off the Beaten Track (Cambridge University Press 2002) 71.

${ }^{5}$ Martin Heidegger, "The End of Philosophy and the Task of Thinking" in David Farrell Krell (ed and trans) Basic Writings (HarperCollins 2008) 435.
} 
resisted the 'planetary imperialism of technically organized man'? Perhaps, as Oscar Guardiola-

Rivera has recently put it, 'only Indians can save our modern soul'? ?f $^{6}$ the crisis of technicity is caused by the forgetting of Being in western metaphysics, then the ongoing "ontological turn" in anthropology that is returning to the question of Being as it is posed in indigenous thought might offer us an alternative future to that of the global domination of technical-scientific rationalityperhaps even a future at all.

But because technicity is the (western) understanding of Being in the modern age, it is not something that we can simply will ourselves out of through engagement with or appropriation of indigenous thought. Indeed, Heidegger himself had made this point when asked in the 1966 interview about a turn to "Eastern" thought as a way out of the enframing of planetary technicity:

My conviction is that only the same place where the modern technical world took its origin can we also prepare an overturning [Umkehr] of it. In other words, this cannot happen by taking over Zen Buddhism or other Eastern experiences of the world. For this overturning of thought we need the help of the European tradition and a new appropriation of it. Thought will be transformed only through thought that has the same origin and determination. ${ }^{7}$

Given Heidegger's dubious illusions of the purity of European, especially German, thought he no doubt overstates his case here. For as numerous decolonial theorists have pointed out, so-called western philosophy has always been produced in a process of "creolization" with the thought of its outside, meaning that there is no purely "European tradition." 8 This is not to say, however, that an "overturning" and "reappropriation" of western thought itself is not necessary: as Brazilian anthropologist Eduardo Vivieros de Castro has put it, we have a lot of ontological work to do in

\footnotetext{
${ }^{6}$ Oscar Guardiola-Rivera, "On the Shaman's Couch: Only Indians Can Save Our Modern Soul” Kindle Magazine 3 April 2014 <http://kindlemag.in/shamans-couch-indians-save-modern-soul/> ${ }^{7}$ As above note 2 at 61.

${ }^{8}$ See for example Enrique Dussel, "Europe, Modernity, and Eurocentrism" (trans Javier Krauel and Virgnia Tuma) (2000) 1(3) Nepantla: Views from the South 465-78; and Françoise Lionnet and Shu-mei Shih (eds) The Creolization of Theory (Duke University Press 2011).
} 
order to make "even disagreement with an animist warrior possible." One such reappropriation is the theory of creolization and the decolonial rereading of the history of modern philosophy in terms of the concept of "coloniality." To be sure, before a real engagement-that is to say, a nonappropriative relation capable of sharing in difference-with indigenous thinking is possible, it is necessary to decolonize the Eurocentric presuppositions of ontology. In this essay, however, I argue that no such decolonial project is possible without also thinking the question of sexuate difference. In this, I follow Luce Irigaray, who has amply demonstrated that western metaphysics- the metaphysics that gives rise to coloniality and planetary technicity—originates in an oblivion of sexuate difference. This oblivion, according to Irigaray, dissociates us from living nature and thus must be attended to before we would be capable of cultivating life, approaching nature, or engaging with another intellectual heritage as anything other than a reserve of resources. Although her work remains controversial in precisely this respect, this is precisely why Irigaray has suggested—in reference to Heidegger's invocation of the saving power of a god-that it is sexuate difference that 'could bring us "salvation" [nous apporterait le «ssalut»]' if we thought it through. ${ }^{10}$ Sexuate difference has such a saving power because, for Irigaray, it offers a 'different articulation of the speaking animal with nature, with matter, and with the body," all of which have been suppressed within the history of western metaphysics, and especially so in the age of modern techno-science. ${ }^{11}$ If our only hope for overcoming planetary technicity, which now implicates the very future of life itself, lies, as Heidegger suggested, in questioning what has been concealed in the unfolding of our epoch, then, as Irigaray has notoriously argued, sexuate difference is indeed "the question of our epoch."

\footnotetext{
${ }^{9}$ Eduardo Vivieros de Castro, "Exchanging Perspectives: The Transformation of Objects into Subjects in Amerindian Ontologies" (2004) 10(3) Common Knowledge 484.

${ }^{10}$ Luce Irigaray, An Ethics of Sexuate difference (trans Gillian Gill and Carolyn Burke) (Athelone Press 1993) 5.

${ }^{11}$ Luce Irigaray, To Speak is Never Neutral (trans Gail Schwab) (Routledge 2002) 229.
} 
Three saving powers: a god, Indians, sexuate difference. How to chart a path between them? By way of setting out on such a journey, this essay has four sections. In the first, I outline Heidegger's account of planetary technicity as the ontology of the modern age, as well as how this relates to what both indigenous activists and Irigaray have understood as a "global death project." In the second, I draw on decolonial theory to situate planetary technicity within the history of the "coloniality of Being," examining the decolonial politics of rethinking ontology. The third section is an exposition of Irigaray's highly original critique of western metaphysics as technophallogocentrism which shows how the death project of technicity originates in the oblivion of sexuate difference and the maternal debt, leading to a autological cosmos framed by the horizon of death and Non-Being rather than relation-in-difference to the other. Here, I defend the inextricability of sexuate difference and decoloniality to any rethinking of ontology capable of confronting planetary technicity. Finally, I conclude by bringing these threads together with the case of the Kogi people of Colombia who have made two documentary films in order to warn the developed world that we will not be able to stop planetary destruction until we re-member the Mother that has been destroyed by technical imperialism. Because the Kogi understanding of Being is entirely structured by sexuate difference and is also an indigenous mode of resistance to the global death project of planetary technicity—one that they seek, at least in part, to share with us-I argue that it allows us to see how the passage from God to the Indians can only take place through sexuate difference. It is only such a passage, I argue, that would permit us to enter into a new constellation of Being, to borrow one of Heidegger's favorite phrases, one that, perhaps, would offer us a chance for life.

\section{Planetary Technicity and the Global Death Project}

Modern technicity, for Heidegger, is identified not with any particular technological modalities or objects but rather by a general ontological comportment in which everything is positioned as 
inventory in a "standing reserve" that is constantly available for human appropriation and manipulation. ${ }^{12}$ Heidegger refers to this comportment as "positionality" (das Ge-Stell) in which Being becomes nothing but a process of ordering the pieces of the standing reserve and thinking takes the form of an instrumental and calculative rationality driven by efficacy and accumulation. While the origin of technicity can be located in the tekhne of ancient Greece, which named the revealing of Being by human know-how rather than by "nature" (physis), with the reformulation of nature as a universal and uniform realm of objectivity within the modern mathematical sciences, modern technicity turns all Being into objects for and of the human subject. ${ }^{13}$ Within the modern epoch, then, technicity is not merely one mode of revealing among others, nor is it the "application" of scientific knowledge; it is the very meaning of Being as such, the a priori condition of all experience, and the fundamental relation to Being necessary for any particular scientific or technological development. If within the Ge-Stell of technicity, all Being is understood as always already standing by (at least as "matter" and "energy") and there is nothing more to be revealed, then humanity is compelled to develop ever-more efficient, precise, and expansive ways of ordering it (hence the insatiable drive that animates technical and scientific "progress"). This is why Heidegger describes positionality the "plundering drive that orders the constant orderability of the complete standing reserve."14 Space exploration, quantum mechanics, the atomic bomb, industrial capitalism, etc. are therefore the almost inevitable outcomes of planetary technicity — that is, of the reduction of everything that is to essentially exchangeable resources in a literally universal reserve. Technicity, then, does not "intervene" in nature, in sociopolitical formations, or in life as if from the outside; rather, it names

\footnotetext{
${ }^{12}$ See Martin Heidegger, “The Question Concerning Technology” in David Farrell Krell (ed and trans) Basic Writings (HarperCollins 2008) 311-41.

${ }^{13}$ See Martin Heidegger, "Modern Science, Metaphysics, and Mathematics" in David Farrell Krell (ed and trans) Basic Writings (HarperCollins 2008) 271-305.

${ }^{14}$ Martin Heidegger, Bremen and Freiburg Lectures (trans Andrew J Mitchell) (Indiana University Press 2012) 31. The 1949 Bremen lectures are the material from which the technics essay is derived.
} 
the Being-technical of the world itself, what Jean-Luc Nancy calls "the ecotechnology that our ecologies and economies have already become."15

Planetary technicity is thus the ontology of the so-called modern globalized world. The positioning of the universe as standing reserve both makes possible the relentless pursuit of accumulation that drives global capitalism and makes necessary the management and administration of these resources on a global scale. From this perspective, seemingly opposed projects such as the ruthless plunder of the global South by multinational conglomerates and development programs that seek to "modernize" these nations, are underwritten by the same onto-logic, the same logic of Being. Regardless of their "own” subjective motivations, humans are themselves conscripted into planetary technicity, which seeks only its own totality. Everything (including humans) becomes the ends and means of everything else as the world becomes nothing but a complex interconnection or "network" of diverse techniques and technologies. From the ever more horrific technics for manufacturing death and debility in wars and occupations to the ever more remarkable technics for manufacturing life and health, from the coal production of China to the green geoengineering of Scandinavia, the planet is nothing but an assemblage of technical possibilities and goals that are ontologically equivalent. In this onto-logic of general equivalence, meaning (i.e., qualitative difference) is produced only through the accumulation of large quantities that must, moreover, be ever-greater in order to even register as value. "Wealth, health, productivity, knowledge, authority, imagination," as Nancy writes, are "all enlisted into the same logic whose general principle seems to be the conversion of quantity into quality. Large numbers lay down the law, whether they be of money, population, speed, power, circulation, information, and so on. In any case, and in the interconnection of all these registers, 'quality,' that is, 'value' or 'meaning' is dispersed in the interactive correlation of all large

\footnotetext{
${ }^{15}$ Jean-Luc Nancy and Aurélien Barrau, What's These Worlds Coming To? (trans Travis Holloway and Flor Méchain) (Fordham University Press 2015) 54.
} 
numbers." ${ }^{16}$ Because nothing has any value in itself, technicity is fundamentally nihilistic: even life and death are significant only to the extent that they contribute to some quantitative aggregate large enough to stand out against the backdrop of general equivalence.

Nevertheless, it is precisely the onto-logic of planetary technicity that many indigenous activist groups in Latin America have identified explicitly as "the death project" of globalization. This onto-logic, as la Asociación de Cabildos Indigénas del Norte del Cauca (ACÍN) puts it, is based on a principle of identity in which accumulation is equivalent to Being. Although they do not do so in the language of Heidegger, and although Heidegger makes very little reference to capitalism or colonialism, they point out that the onto-logic of planetary technicity underwrites both capitalism and imperialism: 'This logic is based in the following:...everything that exists has value only to the extent that it... serves accumulation. This is a logic that leads to the persecution of the people in the territory, the existence of the paramilitaries, the legislation of dispossession, etc. These are only the local and national expressions of the global death project that is transforming life into junk with an intermediate step that is the commodity and the market." 17 This transformation of life into "junk" is what Nancy has called the process of "denaturation" that defines planetary technicity. For Nancy, from its origin in ancient Greece, technicity is a progressive process of converting everything that is into a product of tekhne, that is, of stripping it of any natural ends or principles so that technics can relate only with themselves. Technicity is the end and the means, the only principle in itself: it is only within this process of denaturation that objects pass through the market to generate capital and that

\footnotetext{
${ }^{16}$ Jean-Luc Nancy, After Fukushima: The Equivalence of Catastrophes (trans Charlotte Mandell) (Fordham University Press 2015) 34.

${ }^{17}$ ACÍN, "Tejido de Comunicacíon y Relaciones Externas de la Verdad y la Vida de la Asociacíon de Cabildos Indigénas del Norte del Cauca"

$<$ http://videocomunidad.univalle.edu.co/descargas/Tejido_de_comunicacion.pdf $>$. Translation mine. The phrase "death project [el proyecto de muerte]" appears to have first been used by the Ejército Zapatista de Liberación Nacional, to whom the ACÍN makes explicit reference.
} 
peoples are dispossessed. On this basis, Nancy argues for the "necessity of determining the history of technics up to our time without giving it another meaning in its fundamental contingency than the indefinite relation of technicity with itself and to the escape of its denaturation. One would have to examine, in this respect, the succession of technics... of wealth as such, of production itself (capital, labor), of society (democracy) and finally, of nature itself, or of its complete denaturation, whether by mutation or by total destruction (biological, ecological, ethological engineering).”18 Planetary technicity, then, is both "biopolitical" and "necropolitical" as it works to denature life and death by converting them into objects of technical-scientific representation, production, management, and administration. ${ }^{19}$ Even in contexts where life is fostered for certain populationsan ever-smaller number of populations, of course-this is part of a general process of bringing all lives under the control of economic and political technics within the "global death project" of making waste out of nature: these "lives" are nothing more than inventory in the standing reserve.

For Irigaray, the global death project is explicitly tied to sexuate difference insofar as it is an expression of sexuate, i.e. masculine, Being. In an address given to a group of women after the Chernobyl disaster in 1986, she made this point very clearly:

The death machines are traded around with vast capital expenditures in order to keep the peace, or so we are told....It doesn't have to go this way. It is sexuate. But the technical epoch has given the weapons of war a power that far surpasses the conflicts and risks between patriarchs. Women, children, all that lives, even elementary matter find themselves conscripted bodies and all [s'y trouve embarqué corps et biens]. And this death and destruction cannot be reduced only to war:...technical developments put us to such corporeal tests that we are threatened with physical and psychical annihilation....With the objective purpose of accumulating material goods, and the subjective goal of bolstering the masculine subjective economy, science allows disorder and pollution to increase and then funds various kinds of

\footnotetext{
${ }^{18}$ Jean-Luc Nancy, The Creation of the World, or Globalization (trans François Raffoul and David Pettigrew) (The State University of New York Press 2007) 89.

${ }^{19}$ Indeed, the concept of technique is central to both Foucault's analysis of biopower and Mbembe's analysis of necropolitics. See Michel Foucault, The History of Sexuality, Volume I (trans Robert Hurley) (Vintage Books 1990) and Achille Mbembe, "Necropolitics" (trans Libby Mientjes) (2003) 15(1) Public Culture 11-40. A discussion of the relationship between these two rubrics is beyond the scope of the present essay.
} 
curative medicine....Various pro-birth politics [politiques natalistes] for economic or religious reasons do not prevent the fact that giving life appears as compulsory as destroying it. ${ }^{20}$

Irigaray's point is not (or not only) that the death project is the product of an arbitrary historical exclusion and subordination of women that enables men to control technology on a planetary scale, but rather that the relationship between technicity and masculinity is ontological, that is, that technicity is, in its essence, a "phallomorphic" determination of Being. ${ }^{21}$ Like Nancy, Irigaray partially follows Heidegger in understanding technicity as a progressive process of denaturation that uproots beings in order to master them techno-logically. For her, more significantly, this process "testifies to an oblivion of life, a failure to recognize the debt owed to the mother, to maternal genealogy, to those who carry out the work of producing and sustaining life." ${ }^{22}$ Western metaphysics is therefore a death project from the start because it begins with the ontological annihilation of birth and the living sexuate body; it is only on the basis of this ontological annihilation of life-this Being-toward-deaththat the global death project of technicity, and that European Man's technical domination of the rest of the planet, can proceed. This will become clearer as I elaborate Irigaray's reading of western metaphysics as technophallogocentrism below; however, for now, suffice it to say that Irigaray understands the project of technicity as a sexuate project that is grounded in a desexuation and devitalization of the cosmos, which conflates a phallocentric understanding of Being with Being "as such." Although this argument has, somewhat oddly, been subjected to an enormous amount of criticism in Anglophone feminist theory, it resonates deeply with the indigenous mobilization against the death project. Julia Suárez Krabbe, for instance, writes of how the indigenous peoples of

\footnotetext{
${ }^{20}$ Luce Irigaray, Sexes and Genealogies (trans Gillian Gill) (Columbia University Press) 186-7.

${ }^{21} \mathrm{I}$ am indebted to conversations with Monica Obreja for clarifying this point, which was the subject of her dissertation Technology and Sexuate difference (PhD Thesis, Linköping University 2012). ${ }^{22}$ As above note 19.
} 
Colombia's Sierra Nevada de Santa Marta (including the Kogi) directly tie the planetary effects of the death project to our (i.e., “western”) forgetting of the Mother:

Simplistically put, human rights violations, climate change, illness, wars, earthquakes, and so on happen... because of the world's disequilibrium. This imbalance affects all spheres of life, from the micro and intimate, to the macro structural and macrocosmic. It stems from a lack of reciprocity - more exactly, from some human beings' unwillingness or inability to recompense the Mother for what She has given and to attend to Her teachings. This inability to work with the Mother is part of that which continues to give force to the death project. ${ }^{23}$

From Irigaray's perspective, then, the central question will be: if the death project is a result of a desexuation of the cosmos that grounds western metaphysics on a constitutive matricide, what work woul be necessary in order for us to be able to work with and recompense the Mother?

\section{Coloniality and the Question of Being}

Heidegger was unequivocal in understanding planetary technicity as a form of western imperialism, calling it the 'complete Europeanization of the earth and of man. ${ }^{24}$ For him, the essence of this process is not the global circulation of Euro-American technologies or even the mobilization of technics as instruments of imperial domination, but rather the conscription of the entire planet into the same determination of Being as a standing reserve that is constantly present-at-hand:

Now that modern technicity has arranged its expansion and rule over the whole earth, it is not just the sputniks and their by-products that are circling around our planet; it is rather Being-as-presence in the sense of calculable material that claims all the inhabitants of earth in a uniform manner without the inhabitants of the non-European continents explicitly knowing this or even being able or wanting to know of the origin of this determination of Being. (Evidently those who desire such a knowledge least of all are those busy developers who today are pushing the so-called underdeveloped countries into the realm of hearing where the claim of Being speaks from the innermost core of modern technicity. $)^{25}$

${ }^{23}$ Julia Suárez-Krabbe, Race, Rights, and Rebels: Alternatives to Human Rights and Development from the Global South (Rowman \& Littlefield 2016) 5. Emphasis modified.

${ }^{24}$ Martin Heidegger, On the Way to Language (trans Peter Hertz) (Harper \& Row 1971) 15.

${ }^{25}$ Martin Heidegger, On Time and Being (trans Joan Stambaugh) (Harper \& Row 1972) 7. 
The merit of Heidegger's analysis of planetary technicity is that it allows us to understand the fundamental ontology of global capitalism and globalization that underlies their particular localizations. Nevertheless, his is a Eurocentric analysis of the unfolding of technicity as the ontology of European "modernity," even if it is highly critical of this project as a "conquest" of all other ontologies. But as Walter Mignolo argues, "modernity" is a European narrative that can also be narrated from its underside: coloniality. ${ }^{26}$ As such, planetary technicity is the ontology of coloniality as well as modernity: to study it from this vantage leads both to a richer analysis of its operations and modalities as well as to a different horizon of possibilities for overcoming it. The fact that Heidegger did not consider technicity from the perspective of coloniality is certainly one of the reasons that he grew increasingly despairing about moving beyond it.

The concept of coloniality refers above all to the matrix of power established in the Spanish conquest of the Americas, which inaugurated a new world system. ${ }^{27}$ According to decolonial theorists such as Quijano and Mignolo, it was on the basis of the new forms of power relations developed in the colonial conquest that the major epistemological and economic reformulations

26 “"Modernity' is a complex narrative whose point of origination was Europe; a narrative that builds Western civilization by celebrating its achievements while at the same time hiding its darker side 'coloniality.' Coloniality, in other words, is constitutive of modernity-there is no modernity without coloniality." Walter Mignolo, The Darker Side of Western Modernity: Global Futures, Decolonial Options (Duke University Press 2011) 2-3.

${ }^{27}$ The concept of the "coloniality of power" was first theorized by Aníbal Quijano and has been developed over the course of a now-voluminous body of scholarship. See Quijano, "Coloniality of Power, Eurocentrism, and Latin America" (trans Michael Ennis) (2000) 1(3) Nepantla: Views from the South 533-80. Eurocentric accounts of modernity typically begin with the Reformation (1517), the Peace of Westphalia (1648), and/or the French Revolution (1789), situating colonization as an incidental, even if major, component of this history. Theorists of coloniality, on the contrary, situate the beginning of modernity in a series of events that transpired in Spain in 1492 (its "annus mirabilis"): the fall of Granada that ended nearly 800 years of Islamic presence on the Iberian peninsula, the Alhambra Decree that expelled all Jews who did not convert to Catholicism, the publication of the first grammar of a modern language (Gramática de la lengua castellana by Antonio de Nebrija), and the arrival of Columbus at Guanahani that soon lead to the displacement of the Mediterranean by the Atlantic trade route (see, for example, Dussel above note 8). 
constitutive of "modernity" took place: namely, Reason (which decolonial theorists call "epistemic coloniality"), the state (or "political coloniality"), and capitalism (or "economic coloniality").

Coloniality thus consists of a colonization of space, time, knowledge, exchange, social relations, and so on that subsists and persists beyond any localized colonial contexts and continues to shape the contemporary forms of settler colonization and neo-colonization (or "globalization") today. In an incisive engagement with Heidegger, Nelson Maldonado-Torres adds that coloniality also consists of a colonization of Being itself and argues that by neglecting this, Heidegger's return to the question of Being remains complicit in perpetuating it. I strongly agree with this argument; however, I think that the coloniality of Being should be linked more explicitly to Heidegger's thinking of technicity as the ontology of modernity (Maldonado-Torres does not refer to this aspect of Heidegger' work). ${ }^{28}$ In his Eurocentric analysis, Heidegger locates the origin of technicity in the formulation of the mathematical theory of nature in the modern physical sciences, first in Galileo's experiments with free fall (1604-38) and culminating in Newton's Principia (1687). ${ }^{29}$ While in the Aristotelian cosmology that held sway through the Scholastics, "nature" was thought as a kind of principle of movement internal to bodies that makes them what they are, the mathematical theory reconceives Nature as a uniform space-time context of locomotion of essentially identical bodies. For Heidegger, mathematical science projects onto nature in advance a set of axioms by which it determines what its objects are and how they are to be quantified, measured, and observed. Descartes, in Heidegger's reading, is therefore not at all an "epistemologist," but rather a metaphysician who rethinks Being in accordance with the mathematical sciences' reformulation of beings as objects: with Descartes, the

\footnotetext{
${ }^{28}$ Nelson Maldonado-Torres, "On the Coloniality of Being: Contributions to the Development of a Concept" (2007) 21(2-3) Cultural Studies 240-70.

${ }^{29}$ See Heidegger at note 12, or the (out of print) full lecture series from which this excerpt is taken What is a Thing? (trans WB Barton and Vera Deutsch) (University Press of America 1967). Galileo's experiments took place as early as 1604 although published in his Discorsi in 1638.
} 
"I" becomes the modern determination of the Being of beings, that is, the metaphysical ground or sub-jectum of beings, which become ob-jects that stand against the subject. In this, the principle and origin (the arkhe) of beings is no longer, as it was in the Aristotlean cosmos, nature (or phusis) but rather the knowledge of the human (tekhne). This technical reinvention of nature as a realm of objectivity is thus, for Heidegger, the first step in the accumulation of all that is in the standing reserve, which is why he famously calls modern physics the "herald of positionality." 30

Heidegger's Eurocentric reading of modernity leads him to act as if this reinvention of nature emerges almost ex nibilo—indeed he says that the "provenance" of modern science is "still unknown." ${ }^{31}$ Examining it from the underside of modernity, however, enables a much fuller picture. As Quijano points out, the paradigm of a subject that is for-itself and in-itself and an external object that is for-the-subject, and the paradigm of "nature" as composed of such objects- that is to say, the paradigm of European rationality — "could only have been the product of a relation of coloniality between Europe and the rest of the world." 32 The patterns constitutive of this paradigm can be traced to the early European involvement in the Atlantic, especially the Spanish conquest of the Canary Islands (1402-1496) and the beginning of the Portuguese trade in African slaves (1441). In response to these events, a series of papal bulls were issued between 1452 and 1493 that conferred upon Portugal and Spain the "right of conquest" of all unknown lands, legitimizing the expropriation of territory, the seizure of all goods and resources, and the enslavement all nonChristian peoples "in perpetuity." 33 Such a move marked a fundamental difference from earlier

\footnotetext{
${ }^{30}$ Heidegger as above note 11 at 327.

31 As above.

32 Aníbal Quijano, "Coloniality and Modernity/Rationality” (trans Sonia Therborn) (2007) 21(2-3) 174.

${ }^{33}$ The most significant of these are the "Dum diversas" (1452) and the "Romanus pontifex" (1454) issued by Pope Nicholas V, and the "Inter Caetera" (1493) issued by Pope Alexander VI, which extended the first two into the "New World" after the first voyage of Columbus.
} 
forms of colonization and slavery: it laid down, as an axiomatic law, a basic blueprint according to which land not even yet known was projected as terra nullis and all things (including human beings) not even yet encountered were represented as uniform objects that could be encountered in the same way no matter the specific context. Thus, when the explorers reached "new" lands in Africa and the Americas, they no longer encountered specific places constituted by things of essentially different natures, but rather a ubiquitous "State of Nature" as essentially empty space within which objects without any essential differences could be ordered by the subject in a nearly infinite number of possible arrangements. This establishment of coloniality is thus an axiomatic primitive accumulation that ensures that "nature belongs in advance to the standing reserve of the orderable within positionality." ${ }^{34}$ In this sense, it is coloniality that is the supposedly unknown provenance of modern science, that which first secured "nature" for techno-scientific ordering in the Ge-Stell. ${ }^{35}$ The fact that, in this new understanding of the world, conquest is a taking possession of what already properly "belongs" to the conqueror, is a direct predecessor to the formation of the modern mathematical sciences (and philosophy) in which thinking is an apprehension or representation of what already belongs to the subject. The two faces of the European "Age of Discovery"geographic exploration and scientific revolution—essentially belong together as a taking-possession or

\footnotetext{
${ }^{34}$ Heidegger above note 13 at 39.

35 This point is attested to by direct historical connections: the Portuguese and Spanish expeditions (especially Columbus's 1492 arrival in the Americas) empirically disproved the reigning ChristianPtolemaic geography, which posited that the habitable land of Earth was miraculously floating at the center of the sphere of water. The publication of the first map of this "New World," Martin Waldseemüller's Universalis Cosmographia (1507), led Copernicus to realize that if the ChristianPtolemaic geography is incorrect, then the cosmology of concentric spheres orbiting around the Earth, must also be incorrect. It was Copernicus's revolutionary break with the principle of nonhomogeneity of substance between the terrestrial and celestial realms that enabled the reconceptualization of nature as composed of a homogenous physical substance in Galileo and Newton. The fundamental principle of mathematical science, Galileo's and Newton's "all bodies are measureable," is therefore a direct translation of Columbus's "all seas are navigable." See Sylvia Wynter, "1492: A New World View" in Vera Lawrence Hyatt and Rex Nettleford (eds) Race, Discourse, and the Origin of the Americas: A New World View (Smithsonian Institution Press) 5-57.
} 
accumulation of a world that already lies before the subject: if what is called "discovery" is what Heidegger refers to as the "greed of representational calculation" characteristic of modern technicity then there is no way to rigorously separate the scientist's approach to nature from the colonizer's. ${ }^{36}$ The conquistadors, then, pioneered the first form of modern subjectivity: an individual, self-making agent placed before an external world of calculable objects and whose powers of representation and ordering alone determine all that is. And it is this repositioning of Man's place in the world that will lead to the modern reconceptualization of thinking and of freedom as a going-forth from out of the self, a laying hold or grasping. ${ }^{37}$ In other words, the technical-colonial subject-what Dussel calls the ego conquiro (inseparably combined with the Renaissance humanists' reinterpretation of Man as homo faber)—enables and subtends the other forms of modern subjectivity: rational, political, economic. ${ }^{38}$ To place Heidegger's analysis of technicity as the ontology of modernity within the more expansive historicization of modernity offered by theorists of coloniality is to recognize technicity and coloniality as essential to one another. In this sense, planetary technicity can be understood both as the coloniality of Being (i.e., the ways in which Being is structured by the colonial matrix of power)

\footnotetext{
${ }^{36}$ Heidegger above note 13 at 24.

${ }^{37}$ See Heidegger above note 4 at $81-4$.

${ }^{38}$ Dussel above note 8 . The founding figures of the studia bumanitatis articulated the first "secular" model of the human- "Man"-through their "rediscovery" of pre-Christian Greco-Roman philosophy that allowed them to break entirely with the reigning theology of Medieval Scholasticism, which placed the human at a fixed position in the Great Chain of Being such that the only worthy knowledge was study of the ecclesiastical texts. In this reinterpretation of the human, Man is the maker of himself, thus individual discovery and knowledge are of the utmost importance. In this, there was a reciprocal influence between the humanists and the early explorers (such as Columbus and Prince Henry "the Navigator"). Consider, for instance, how Pico della Mirandola reinterprets the "fall" of Adam in his Oration on the Dignity of Man (1486), which has been called the "manifesto" of the Renaissance: "Adam we give you no fixed place to live, no form that is peculiar to you... According to your desires and judgments, you will have and possess whatever place to live, whatever form, and whatever functions you yourself choose....You with no limit or no bound may choose for yourself the limits and bounds of your nature... you may fashion yourself into whatever form you choose." It was Pope Nicholas V, the author of the papal bulls bestowing the "right of conquest," who encouraged the development of the humanities, which earlier popes had seen as heresy.
} 
and as the Being of coloniality (i.e., as the determination of Being that underwrites coloniality). As such, the Heideggerian ontological difference between Being and beings must be thought alongside what Maldonado-Torres calls "colonial difference" (or "sub-ontological” difference). ${ }^{39}$ As Heidegger shows, the objectification of all beings (human and non) in technicity takes place on the prior oblivion of Being that characterizes the history of western metaphysics: it is the nihilation of Being that first reduces Being to the sum of present-at-hand beings and then this to a standing-reserve of objects. But because western philosophy had, since Parmenides, thought Being in terms of a monotheistic onto-theology of the One, Being could only be thought vis-à-vis Non-Being or Nothing. Thus, even after Being had been reduced to a standing reserve of objects, even after Man had killed God, the western ontology remained a "monotheistic" thinking in which what is outside of Man's world-picture (i.e., the sum total of representational ordering) does not exist. In order to bring everything into this world-picture, then, the process of colonization consisted of a double movement in which all beings encountered by the technical-colonial subject were stripped of any ontological status (i.e., their Being was nihilated) while they were also objectified as beings. ${ }^{40}$ Contrary to standard accounts, then, when colonized peoples encountered the European colonizers, they faced something far more formidable than technology and weaponry that was simply more sophisticated than their own: they were up against the first understanding of the world without Being, the technical world in which all that is already belongs to Man as the object of his manipulation. This annihilation of Being, however, nevertheless remains a determination of Being and thus planetary technicity is an ontology without Being, like a monotheistic world without God.

\footnotetext{
${ }^{39}$ As above note 27.

40 The first process is what Frantz Fanon means when he describes the colonized as being trapped within a "zone of non-Being," while the second is captured in Aimé Césaire's famous equation "colonization=thingification." See Fanon, Black Skins, White Masks (trans Richard Philcox) (Grove Press 2008) xii and Césaire, Discourse on Colonialism (trans Joan Pinkham) (Monthly Review Press 2000) 42.
} 
The project of colonization, then, had to actively destroy indigenous ontologies-which were not (and are not) viewed by the technical-scientific-colonial subject as different constellations of Being (since Being had already been nihilated) but rather as false views of the singular cosmos of Man (which is all that exists) — in order to impose the ontology of technicity on the planet. The reason why planetary technicity holds such a hegemonic grip is precisely because, in annihilating Being as such, it has enabled the conflation of the technical-scientific world-picture of Man with Being itself. This is precisely what has been challenged by the recent "ontological turn" in anthropology, which seeks to move beyond the ethnographic study of different "world-views" (which presumes the singular world of Man) to the study of different conceptual worlds. Understanding indigenous thought as ontology challenges the coloniality of Being of planetary technicity, or what Viveiros de Castro refers to as the western "absolute ontological monarchy" that "derealizes" all non-Euro-American thought, for in this gesture Being must no longer be thought in opposition to Non-Being but rather in relation to Being-as-other. ${ }^{41}$ In this way, Viveiros de Castro calls ontological anthropology "a practice of the permanent decolonization of thought," which is why what Heidegger called the "question of Being" is the most political question of all. ${ }^{42}$

\footnotetext{
${ }^{41}$ Eduardo Viveiros de Castro, The Relative Native: Essays on Indigenous Conceptual Worlds (Hau Books 2015) 54. Viveiros de Castro is aware that making an "ontological" approach foundational risks making the European thinking of Being axiomatic, but argues that it is at the very least "tactically" necessary: "The image of Being is obviously dangerous analogic ground when it comes to anthropological re-imaginings of non-western conceptual imaginations, and the notion of ontology is not without its own risks.... Nevertheless, I think the language of ontology is important for one specific and, let's say, tactical reason. It acts as a counter-measure to a derealizing trick frequently played against the native's thinking, which turns this thought into a kind of sustained phantasy, by reducing it to the dimensions of a form of knowledge or representation, that is, to an 'epistemology' or a 'worldview.' As if whatever there is to know or view was already decided beforehand-and decided, of course, in favour of our ontology. So the notion of ontology isn't evoked here to suggest that all thought, be it Greek, Melanesian, African, or Amazonian, expresses a metaphysics of Being, but to underline the fact that all thought is inseparable from the reality which corresponds to its exterior" ${ }^{42}$ Viveiros de Castro as above at 75.
} 
4. Luce Irigaray and the Matricidal Meta/physics of Technophallogocentrism

Throughout his work, Heidegger was preoccupied with the question of the relationship between the history of western metaphysics and the rise of planetary technicity: how exactly did the oblivion of Being in ancient Greece give way to the positioning of all that is in the standing reserve of modern technology and science? As is well known, Heidegger locates the origin of western metaphysics in a series of reductions of the ancient Greek thinking of physis, which originally named the general process of emergence and abiding, or Being as such. When the first philosophers sought to understand to understand Being itself without recourse to what we would now call the supernatural (as in mythological thinking), they did so by way of "physical beings" (ta physei onta), thereby opening the door for the meta-physical approach to the question of Being by way of beings. ${ }^{43}$ Once Being is understood in terms of beings, however, the thinking of Being (phusis) as a process of emergence and abidance is forgotten in favor of present beings and tekhne (the know-how of humans) will gradually replace physis as the origin and principle (arkhe) of all that is. In the age of planetary technicity, Heidegger argues that a return to the pre-Socratic "first beginning" of metaphysics is necessary in order to recover something of this forgotten thinking of physis. In her extended engagement with Heidegger, Irigaray partly follows his return to the pre-Socratics, but she argues that what was forgotten at the beginning of metaphysics was not Being, but living and, therefore, sexuate difference. In her book on Heidegger, L'oubli de l'air chez Martin Heidegger (1983), Irigaray points out that with the thinkers to whom Heidegger returns (Parmenides and Heraclitus), physis is already gathered by the logos, cut off from its material generativity (genesis), which has been given over to the language of Man. In other words, it is already here that the foundational tautology of western metaphysics in

\footnotetext{
${ }^{43}$ See Heidegger, Introduction to Metaphysics (trans Gregory Fried and Richard Polt) (Yale University Press 2000).
} 
which Being (physis) is "the same" as thinking (logos) is in play for "the elementality of physis—air, water, earth, fire—is always already nihilated by [Man's] own element: his language."44 Moreover if, as according to Heidegger, it is this thinking of physis in Parmenides and Heraclitus that constitutes the first thinking of Being as such and, for both of them, Being is conceptualized as eternal, solitary, and without generation, then Being 'itself' — from the very beginning - is constituted precisely as a meta-physical oblivion of physis. By detaching physis from its material element and substituting the logos as the matrix of the cosmos, physis no longer holds sway as the self-generating source of bringingforth that coexists with tekhne. Rather, Being is equated with what has been gathered by the logos and thus tekhne, the know-how of man, becomes the arkhe of all, positioning and ordering nature long before the rise of modern science and technology. As Irigaray writes:

Tekbne is now the arkhe of the whole: the framing of the world is tekhne and it forgets the origin that is nature. Physis is always already subjected to technology and science: that is, to the technology and science of the logos. In these, something of the manner in which physical beings grow is lost. Things, cut from their natural enrootedness, float about, wandering the propositional landscape. The phuein of physical beings is forgetten in the physis of the logos. The physical constitution of beings is forgotten in the metaphysics of Being. Nature is recreated by the logos. ${ }^{45}$

The logos therefore constitutes what Irigaray calls the "architechne," the originary technics by which Man usurps the generative power of physis for his own refashioning of the world. And this therefore means that the materiality of physis, especially the insensible air, is always already enframed as a standing reserve by and for the technical positionality (Ge-stell) of the logos. For Irigaray, then, what metaphysics "forgot" in the enframing of physis was not, as Heidegger would have it, Being, but rather vital materiality as a living process. The "oblivion of Being" so extensively analyzed by Heidegger thus covers over an even prior oblivion. And the fact that this living materiality was already forgotten by

\footnotetext{
${ }^{44}$ Luce Irigaray, The Forgetting of Air in Martin Heidegger (trans Mary Beth Mader) (University of Texas Press 1999) 74.

${ }^{45}$ Above at 86.
} 
the first thinkers of Being explains why, when Heidegger looks to their works to recover a thinking of Being after its metaphysical oblivion, it takes the form of a Being-toward-death: the Being that he is looking for has always already been constituted in opposition to living. For Irigaray, Heidegger's "hostility" to science and technology, and his notorious difficulty in grappling with the relation between life and Being, are therefore indicative of his desire to preserve the logos as the exclusive site of the revealing of Being: for her, the House of Language is the very architectonics of metaphysics.

In her reading of the history of metaphysics, Irigaray directly connects this forgetting of the vital materiality of phusis to a forgetting of sexuate difference. This occurs first through the forgetting of birth and the role of the maternal-feminine. In the pre-philosophical cosmogonies, the general process(es) of emergence and transformation (phusis and genesis) are thought explicitly in terms of birth, as evinced by the respective roots of these words (phuein and gignomai), which mean "to beget" and "to be born." With Heraclitus and Parmenides, however, phusis-as-Being is understood precisely as "that which has no birth" (ageneton, Parmenides) or "that which always ways" (aei esti, Heraclitus). In this, the generative materiality of what Irigaray calls both "mother-nature [mère-nature]" and "mother-matter [mère-matière]" has always already been appropriated, for it is no longer nature, matter or the mother that are the source (arkhe) of being(s), but rather the logos. In other words, for these thinkers, it is only within the logos that Being and beings emerge and abide. For Irigaray, this amounts to the uprooting and gathering of beings in the logos of Being, an airless space that exists parallel to the "natural" world in which there is no birth, growth, or change except through their mimesis in the form of thinking and saying. But, Irigaray queries, without matter, without nature, without having been born, how does the philosopher think and speak? How do Being and beings come into appearance? Is birth not the first, and in fact only, passage into Being and thinking? For Irigaray, mother-nature-matter is that which gives herself endlessly without return, but her ceaseless giving is 
replaced by the gift that has always already been given without a giver. ${ }^{46}$ Western metaphysics is therefore founded on a constitutive matri-cide: an elimination of the mother and of matter. To recover the vital materiality of physis means also to recover the "debt of life" to she who gave and gives it: mother-nature-matter.

This matricide at the origin of metaphysics leads to the metaphysical oblivion of the sexuate other. In pre-philosophical Greece, as in many other cultures, the cosmos was fundamentally divided in terms of sexuate difference. For instance, ancient Greek nouns, according to Cornelia Tsakiridou, are gendered not merely in a grammatical or logical sense (as in Latinate languages) but rather ontologically. In other words, it is not that certain nouns are associated with certain gendered norms but rather that they arise from and express a particular sexuate relationship to the world. Gender functions in ancient Greek, Tsakiridou writes, "as a sensual catalog of the human lifeworld." ${ }^{47}$ Thus, feminine words-e.g., physis, genesis, poiesis, arkhe-express patterns and relationships that have “natural equivalents or analogs" with feminine morphology, sexuality, and life processes, such as internalization, fluidity, embodiment, birth, materiality (and the reciprocal for masculine words). ${ }^{48}$ This means that the way that phenomena were designated in language—not just in the name, but in

\footnotetext{
${ }^{46}$ As Irigaray uses air as a synecdoche for the forgotten elemental materiality, she uses it also to recover the forgotten mother-nature-matter: "She gives [Elle donne] — first—air, and does so irrecoverably, with the exception of the unfolding, from and within her, of whoever takes air from her. While this air is - first - fluid matter carried by the blood she gives, it can also be understood as voice and phenomenon. These issue from it and are the possibility_ever material_ of namingdemonstrating, of appearing in presence. She gives first. She gives the possibility of that beginning from which the whole of man will be constituted. This gift received with no possibility of a return. He cannot pay her back in kind" (Above at 28). The use of the singular pronoun "elle" throughout Irigaray's later works is meant to signify a sort of consubstantiality of the referents: mother, nature, matter, woman. Similar to Trinitarian theology, these are distinct yet are of the same "substance" (or lack thereof) as configured within metaphysics.

${ }^{47}$ Cornelia A Tsakiridou, "Philosophy Abandons Woman: Gender, Orality, and Some Literate PreSocratics," in Emanuela Bianchi (ed) Is Feminist Philosophy Philosophy? (Northwestern University Press 1999) 248.

${ }^{48}$ Above at 234.
} 
the experience and delimitation of the phenomena itself-reflects a specifically sexuate mode of Being. For example, the feminine word for "language," glossa, emphasizes an embodied dimension of speech (i.e., the tongue), while the masculine word logos is more abstract, placing the emphasis on the utterance itself. In pre-literate Greek, then, the feminine and the masculine are two orientations toward the world, arising from particular relational and morphological contexts, with each serving as the limit and horizon of the other, and the interaction between the two producing the total reality of the Greek cosmos. As such, dialogue is a relation of desire for a perspective on the whole. ${ }^{49}$ According to Tsakiridou, the emergence of Greek literacy signals the collapse of this sexuate cosmos. Reading the earliest written texts in the philosophical tradition — the fragments of Anaximander, Parmenides, and Heraclitus_-what Tsakiridou observes is not, as is commonly held, the first attempt at a "rational" understanding of the cosmos but rather the first description of the cosmos without sexuate difference. When the philosopher becomes the arkhe of his own text, language becomes monologic and thus loses its embeddedness in the sensual (and sexuate) realities of living. An entirely new experience of the world therefore becomes possible: like the text, the cosmos itself becomes represented as a singular totality, without birth (genesis), detached from the vital materiality of nature, mother, and the sexuate living body. And because the feminine no longer functions as a limit-horizon, the sexuate other is no longer necessary in order to have a perspective on the whole, for the singular logos can gather all. It is

\footnotetext{
49 " [TT $]$ he feminine is not only a grammatical structure. It is also a certain intuition of world and a way of directing myself in it...In that context, it makes sense to say that the masculine becomes a limit, an encompassing intuition of otherness in things — similar to what the phenomenologists like to call a horizon. Within that horizon and its dynamics, a multiplicity of relations is possible which invokes but also challenges that limit. The same applies to the other side: the function of the feminine as a horizon for the masculine. The interaction of these two horizons produces the space delineated by the total reality of the Greek language-I can put this in a somewhat poetic way by calling that reality the Greek cosmos... [Greek] can speak from the body's other and from the difference of its desire toward the whole world" (Tsakiridou as above at 238 and 248).
} 
this neutered cosmos, i.e., "Being itself," that will become the cosmos of metaphysics. ${ }^{50}$ Once the feminine has been removed as a limit, the masculine perspective becomes the whole cosmos (i.e., "Being itself"); and yet, in order to present itself as neuter, the feminine must be actively annibilated. In this, the horizon of Being, or what lies beyond the limits of the world of the philosopher-physicist, becomes Non-Being or Nothing, rather than Being-as-Other. ${ }^{51}$ Within this neutered cosmos, natural differences are supplanted by logical dualisms that only simulate difference within a logos that can speak only of and to the Same. Without a birth and without her, without difference, this Being can only be a Being oriented toward Nothing: a "Being-toward-death." Framed by death and by the Nothing, how could this neutered Being unfold as anything other than the nihilism of planetary technicity?

As the nihilation of Being in western metaphysics nevertheless remains a determination of Being, the desexuation of the cosmos nevertheless remains a sexuate cosmos for if there is any point that Irigaray has made clear in her oeuvre, it is that so-called neutrality is nothing but an alibi for the reign of the masculine. Thus, while the written text and philosophical thought enabled the neutralization of cosmology, the experience of the world codified there was not neutral, but specifically masculine. Indeed, as Tsakiridou notes, it is not that a new, neutral vocabulary was invented to express this new, neuter cosmology; rather what was new was that this cosmology was expressed in an entirely masculine vocabulary, with the feminine no longer being necessary to

\footnotetext{
${ }^{50}$ As Irigaray puts it: "In order to definitively close the logos upon itself, in order for the logos to speak with itself, the traces of a relation with her are said in the neuter. For example, On in the singular is used to designate the totality of beings - there is $\mathrm{On}$ - and the beings are named onta - there are onta. Instead of saying: the world is born from her, and from my relation with her, the Western philosopher says: there is [it gives, Es gibt] Being, there are beings, which is, or are, without anyone who gives. There is, there are, without being born in a way, without any origin. There is, there are, mysteriously there. With the neutralization of his own being and of the whole of the universe, the Presocratic philosopher somehow prepares our tradition for nihilism." Irigaray, In the Beginning, She Was (Continuum 2013) 4.

${ }^{51}$ As Heidegger writes of Parmenides: "Inasmuch as Being has to be distinguished from an Other and reinforced as physis, Being is distinguished from not-Being" (above note 42 at 115).
} 
express the whole. In philosophical texts, words that had once expressed a sexuate experience of the world became "asexual and asomatic beings" and this de-materialization and de-sexuation of language and experience enabled the masculine world to present itself as neutral truth or reality, while the feminine world was silenced. ${ }^{52}$ Logos, for instance, was no longer a distinctly masculine experience of language that coexisted with glossa, but rather became language itself. And because, as Irigaray argues, the logos is the architectonics of metaphysics, metaphysics is isomorphic with the masculine world. Western metaphysics, that is to say, is techno-phal-logo-centric it is the technical reconstruction of the world in the image or form of Man through the $\log 0 . .^{53}$ For Irigaray, Man is therefore "essentially technocratic," for with the banishment of birth (genesis) and living material nature (phusis) from his cosmos, tekhne would be the only mode of Being available to him. ${ }^{54}$ As the necessary condition of all Being and thinking, without any place of her own within this metaphysics, she (mother-nature-matter-woman) is always already positioned-having been plundered — as the standing reserve out of which Man builds his dwelling. Through her famous psychoanalysis of the unconscious of western philosophy, Irigaray therefore reveals that in the same way that the barring of the relation to the mother forms the unconscious ground upon which phallic subjectivity is erected, the burial of "mother-matter" forms the "mute soil" of meta-physics. ${ }^{55}$ By displacing (1)

\footnotetext{
52 Tsakiridou above note 46 at 248.

53 "Language [le langage] would be the technology—-the architechnology, the architectonics—for man's fashioning the living according to his sexual project" (Irigaray above note 43 at 91). Thus, as Claire Colebrook points out, it is not that Irigaray merely associates the history of metaphysics with "masculine values," but that metaphysics signifies a sexuately "specific relation to Being," that of phallogocentrism. Claire Colebrook, "Feminist Philosophy and the Philosophy of Feminism: Irigaray and the History of Western Metaphysics" (1997) 12(1) Hypatia at 86.

${ }^{54}$ Irigaray as above at 90.

${ }^{55}$ In Speculum, Irigaray reads the history of philosophy in specifically psychoanalytic terms, to which I refer with my choice of language here. In Lacan's theorization of the phallic symbolic, the originary "fusion" (or so it is understood in psychoanalysis) with the mother must necessarily be severed and barred by the phallic signifier in order for the subject to constitute himself as such within the symbolic order. This barred relation to the mother cannot be given symbolic representation except through metaphoric substitutions and metonymic displacements. The maternal-feminine is therefore
} 
birth, (2) vital materiality, and (3) sexuate other(s) from his cosmos, the Being of Man has always been a death project, a violent conquest of her that is oriented only toward Nothing. As Irigaray writes:

This would be the "as such" [soi-même] of western man: the effect of a mastery, of a violent domination over the natural universe and not of a respect for, a contemplation of, a praise for, or an alliance with it. The history constructed by man resembles a history of enduring violence, of appropriation, of domination... Man has created, invented, and given to nature not so much because he was more than her, but because he wished to tame her. It this not, perhaps, because he was less than her?...The Being of man is constituted thanks to the limit of death: he has nothing which can overcome it. The fact remains that man places himself here on earth in a circle woven of violence and terror, thus closing every opening. ${ }^{56}$

Here, the world becomes nothing more than the sum total of Man's technical ordering powers. In other words, what Heidegger calls the "conquest" of the world as Man's picture is the "grounding event" not, as he would have it, of modernity but of metaphysics. Detached from living materiality or nature in its difference, the world of metaphysics becomes synonymous with the techno-logically positioned world of Man in which to be is to be an object of Man's re-presentation (beyond which is simply Nothing). On Irigaray's reading, then, the age of planetary technicity is the culmination of the metaphysics of technophallogocentrism.

\section{A Chance for Life: Sexuate Difference and Decoloniality}

Irigaray and Heidegger offer what are arguably the two most incisive Eurocentric critiques of western philosophy, enabling us to understand the modern world in its ontological and metaphysical foundations. Through their work we can understand planetary technicity as a metaphysical death project

represented as the undifferentiated ground (i.e., "the Real" in Lacanian terms) against which the phallic barrier must be erected in order to prevent the subject from falling into the black hole of psychosis. Irigaray argues that this phallic imaginary subtends the entire history of metaphysics, which for lack of finding symbolic representation for the maternal function, has erected an ontotheological and phallic barrier against what it takes as undifferentiated materiality. This materiality can then only resurface in metaphors and metonymies, or as a traumatic return of the Real.

${ }^{56}$ Luce Irigaray, To Be Two (trans Monique Rhodes and Marco Cocito-Monoc) (Routledge 2001) 714. 
that consists of the substitution of a singular techno-logically ordered world for living nature in its material difference. Through this process of "denaturation," all beings (including humans) are withdrawn from their vital, material, morphological becoming and gathered in a universal standing reserve of resources that can be put to whatever use. In such a world, any difference is the result of the production of value out of general equivalence and all relations are technically mediated interactions driven by calculative, accumulative, instrumental rationality. According to Heidegger and Irigaray, it is only within the context of such a metaphysics that capitalism, colonization, and globalization can arise. As such, any fundamental challenge to these systems must proceed by way of another thinking of Being than the onto-logic of planetary technicity. While for Heidegger, the reach of technical rationality is so exhaustive that the only remaining possibility is what he called a "commemorative thinking" that reflects on the oblivion of Being while preparing a place for "its" return, Irigaray's critical engagement with Heidegger reveals that even more than Being, life is the unthought condition of western metaphysics that remains in reserve within it. For Irigaray, then, the only possible challenge to the reign of planetary technicity is the "reawakening of life":

In order to go beyond a conception of the world that a technical way of thinking and behaving governs, we must discover another frame or structure thanks to which human beings may escape such domination while acknowledging and interpreting the nature of its power. We must free ourselves from the technical and scientific ascendance over our epoch and ensure the safeguarding of meaning by a new incarnation of being. In reality, the meaning that we must consider and cultivate in our epoch is first that of life itself. ${ }^{57}$

According to Irigaray, rebuilding the world beyond the metaphysics of technophallogcentrism requires beginning again from life itself as an ultimate and irreducible value. Within such a framework, Being and thinking would cultivate what life is in its morphological specificities, which would prevent the gathering of everything that is into a standing reserve of general equivalence. Life, as Irigaray puts it, is nonnegotiable: once it is not cultivated in itself, it is already appropriated by the

\footnotetext{
${ }^{57}$ Luce Irigaray, To Be Born (Palgrave 2017) 88.
} 
death project. ${ }^{58}$ Here, Irigaray is aligned with indigenous activists, such as the ACÍN, who see the affirmation of life as the only possible resistance to the global death project because only life can be an end in itself: "Life can never be a means to another end, and even less to that of accumulation. Life is the only end....There are two opposed projects: the death project and the plans of life." ${ }^{59}$

It is the question of an ontology of life that can therefore ground a decolonial feminist challenge to the death project of planetary technicity. While the question of life has been a growing concern in recent feminist theory, it is often approached by way of seeking a closer engagement with the sciences. ${ }^{60}$ However, "life" as it is understood within the sciences is ultimately a technical object and, as such, cannot ground any alternative to planetary technicity. While this certainly does not mean opposing the sciences, it does mean that feminist theory must generate its own concepts of life instead of drawing them from the resources of technophallogocentrism. In this sense, an engagement with intellectual heritages that have resisted and survived the imperialism of planetary technicity is indispensable. Indeed, even Irigaray argues that because "life can never be treated as an object, our culture [i.e., Eurocentric thought] does not supply us with a method to answer" the question of how to cultivate life itself. ${ }^{61}$ And yet, this is where the question of sexuate difference becomes an inextricable dimension of this project. As Irigaray's work demonstrates, the death project of planetary technicity is accomplished through the ontological annihilation of birth and sexuate difference that enables the entire cosmos to be molded isomorphically with (western) Man's imaginary and desires (themselves often unconscious). Again, Irigaray's claim here is not the same as the relatively common anthropological-historical argument (initiated by JJ Bachofen and Friedrich Engels

\footnotetext{
${ }^{58}$ As above note 1.

${ }^{59}$ As above note 17.

${ }^{60}$ See Hasana Sharp and Chloe Taylor (eds) Feminist Philosophies of Life (McGill-Queen's University Press 2016).

${ }^{61}$ As above note 1.
} 
and developed in much "second wave" feminist scholarship) that the overthrow of "mother right" and the subordination of women is the basis for all subsequent systems of exploitation including colonization and capitalism. It is, rather, a philosophical argument that the ontology-the specific a priori determination of Being - that subtends colonization and capitalism, that is planetary technicitycoloniality, is the culmination of the metaphysics of technophallogocentrism which begin with the ontological annibilation of sexuate difference and material-maternal generativity. It is on the basis of this annihilation that the fabricated world of technicity has been constructed—a fabricated world that, once again, is not neutral, but is essentially phallomorphic. For Irigaray, because the entire technicalcolonial onto-logic is structured and systematized by a symmetry that is constitutively incapable of recognizing living difference, we are not able to approach indigenous thought as different—what Viveiros de Castro calls "Being-as-Other"-without appropriating it to the metaphysics of the Same unless we are able to live and think sexuate difference. It is for this reason that Irigaray has controversially insisted that, in the age of globalization, sexuate difference is necessary in order to be able to meet and respect and differences between cultures and to cultivate a shared world without the imperialism of western onto-logic. ${ }^{62}$ While Irigaray has often been critiqued for universalizing a specifically Eurocentric formation of sex/gender, her work is, to my mind, actually quite consonant with the work of decolonial feminist theorists. For instance, in her critique of Quijano, María Lugones has shown that the coloniality of power and Being did not merely shape existing patterns of sexuality and gender but were themselves imposed in and through Eurocentric norms of sexuality and gender, often introducing sex and gender as sociopolitical categories where they were not

\footnotetext{
${ }^{62}$ See, for example, "Toward a Mutual Hospitality" in Thomas Claviez (ed) The Conditions of Hospitality: Ethics, Politics and Aesthetics on the Threshold of the Possible (Fordham University Press 2013) 42-54 and A New Culture of Energy: Beyond East and West (trans Stephen D Seely) (Columbia University Press 2017).
} 
previously operative. ${ }^{63}$ As she argues, this was done through the destruction of indigenous cosmologies in Africa and the Americas that had their own erotic choreographies that were often not limited to binary notions of gender and sexuality restricted to individualized and bounded bodies categorized by reproductive function and genitalia. This understanding of sexuality and gender, however, is itself a product of the onto-logic of technicity in which sex and gender are technical objects always already detached from vital, material difference ${ }^{64}$ —an understanding which, as discussed above, is itself constructed on the obliteration of pre-philosophical Greece's sexuate cosmology. Thus, when Irigaray claims that "all traditions that remain faithful to the cosmic take account of natural powers in sexuate terms," or when she suggests that an attunement to sexuate difference is necessary in order to be able to affirm any other differences, she is not seeking to make Eurocentric sex/gender formations_-which she herself challenges since the beginning of her work as a "regime of sexual indifference"—a transhistorical universal and the basis and priority of any global feminism. ${ }^{65}$ Instead, her point is for those of $u s$ within the onto-logic of technophallogentrism: because our metaphysics is grounded in an annihilation of life and sexuate difference, we must work this out before we can have any non-appropriative encounter with nature or with the other, any relation-in-difference that is capable of respecting life itself without imposing our own (physical or logical) forms on it. This is why, in her post-Chernobyl address in which she argues that the global death project of planetary technicity is a sexuate project, she insists that a new ontology, ethics, and politics of sexuate difference is "a chance for life."

\footnotetext{
${ }^{63}$ María Lugones, "Heterosexualism and the Colonial/Modern Gender System" (2007) 22(1) Hypatia 186-209 and "Toward a Decolonial Feminism" (2010) 25(4) 742-59.

${ }^{64}$ This technical-scientific understanding of sex/uality is what Foucault theorizes as the Scientia sexualis and the "dispositif of sexuality" which "grips bodies in their materiality, their forces, energies, sensations, and pleasures." See The History of Sexuality Volume One (trans Robert Hurley) Vintage Books 1990) 155.

${ }^{65}$ Luce Irigaray, Sexes and Genealogies (trans Gillian Gill) (Columbia University Press 1993) 108.
} 
By way of conclusion, then, I would like to offer one example of a decolonial response to the global death project that is grounded in a sexuate cosmology: that of the Kogi people of the mountains of the Sierra Nevada de Santa Marta near the Caribbean coast in northern Colombia. The Kogi are descendants of the Tairona cultures who had already moved from the coast into the mountains by the time of Spanish invasion and therefore escaped the total decimation that was the fate of so many other indigenous peoples, making them one of the most intact pre-Columbian cultures. ${ }^{66}$ Although the Kogi live in accordance with their ancient practices (including choosing not to adopt writing or learning Spanish) and do not welcome outsiders, in the late 1980s they contacted BBC filmmaker Alan Ereira telling him they have a message for the western world, which they refer to as the "Little Brother." This message, offered at the same time that scientific hypotheses about climate change first began to be taken seriously in the global north, warned of impending ecological catastrophe, increasing geopolitical unrest, and serious heath crises. According to them, this is happening because the death project of planetary technicity has forgotten our common Mother and thus mutilates the Earth without understanding its essential interconnection. Given that we obviously did not heed their message and their predictions came true, they reached out to Ereira again to give their "final warning" in the documentary Alúna (2012). Because there is so little time left, in this film, unlike the first, they focus on actually teaching their cosmology and scientific practices so that we can better grasp their ecological message.

The Kogi cosmology is extremely complex and can be presented in both "philosophicalscientific" and "mythological-religious" forms, "both" of which are centered on the Great Mother. In her meta/physical form, the Mother is called aluna, which is the fundamental and incorporeal lifeforce of the universe, generative energy, concentrated thought, the intelligence of Being:

\footnotetext{
${ }^{66}$ The other three descendants of the Tairona (who also live in the Santa Marta) are the Arhuaco, Kankuamo, and Wiwa.
} 
Aluna contains everything which is past and everything that may become. Aluna is intelligence; it is the concentrated thought and memory which forms a bridge between the human 'spirit' and the universe, but it also the hidden world of forces which govern the world's fertility. Alina makes possible growth, birth, and sexuality; it is the 'spiritual' energy that makes things happen. If it did not, the world would be sterile. It would never have begun. Alina was and is the Mother. ${ }^{67}$

By dividing herself between memory and possibility, the Mother ceaselessly gives birth to material reality, which exists only in the present, teetering on the threshold of the immaterial past and future in a constant process of creative (re)generation. ${ }^{68}$ Unlike in western cosmology, ancient and modern alike, the origin was not an unruly and undifferentiated chaos that would need to be ordered by a God, a demiurge, a logos, or a rational subject who would cut us off from mother-nature. The Mother always was and, as in pregnancy, even before giving birth there is morphological differentiation within her. Based on this, the Kogi view the entire cosmos as living; indeed, they refer to the cosmos as the "fabric of life" (aluna zakwa) which is woven by the Mother on a cosmic loom using the thread of aluna. Alúna is thus the incorporeal tissue out of which the material flesh is made. This cosmic fabric, moreover, is sexuate: the warp threads are feminine (Seynekun), giving the fabric its structure, form, and strength, while the weft threads are masculine (Seranwka) which give the fabric its pattern, appearance, and texture. In this fabric, every "point" in the cosmos, every pick in the weave, is a meeting between masculine and feminine and thus every being has a "mother" and a

\footnotetext{
${ }^{67}$ Alan Ereira, The Elder Brothers' W arning (Tairona Heritage Trust 2008) 110-1. Ereira's text is written in collaboration with Ramòn Gil, who as one of the few Kogi fluent in Spanish acts as a sort of spokesman. See also, "The Law of Sé: Linking the Spiritual and the Material," which is Gil's presentation of the Kogi cosmology translated by Ereira with an exegesis that situates it in relation to western concepts in Barbara Hoffman (ed) Art and Cultural Heritage: Law, Policy, and Practice (Cambridge University Press 2006) 21-7. Ereira notes that although the Kogi have never been converted to Catholicism (it is in no way a "syncretic religion"), Colombian Spanish itself carries its own Catholic "baggage" and that Gil's use of certain words like "spiritual" should be understood with this in mind.

${ }^{68}$ As they describe it, in order to give birth to the physical present, the mother split the past ("memory") and the future ("possibility"), which are not physical and are not split in the nonphysical realm $(S e)$. The physical present is thus situated in a sort of vaginal opening between the past and the future which remain in continuous contact like lips.
} 
"father." ${ }^{99}$ For the Kogi, this macrocosmic ordering principle also structures microcosm, for every element of social life including language is "constructed out of the partnership of masculine and feminine, the dynamic process of weaving on the loom of life."70

Again, however, the Kogis' cosmology is not only mythological, and is not at all some form of "irrational superstition." For them, on the contrary, material reality is underpinned by a complex yet ordered immaterial axiomatic infrastructure, Sé, which includes everything that exists (but much more than materially exists) and is bound to material reality by the thread of aluna. Sé is not a transcendent "realm," but the incorporeal sense and structure of Being. Because alina is both concentrated thought and life-force, and because material life and consciousness are therefore a sort of dilated alúna, humans can access Sé through concentrated thought. ${ }^{71}$ This, as one might guess, is no small feat and, indeed, can generally only be done by the Mamas, who are the Kogi's scientists, philosophers, physicians, lawyers, and spiritual leaders-i.e., the keepers of the "Law of Sé." Because

${ }^{69}$ Indeed, even their technical artefacts are sexuate: "The idea of the balance between the masculine and the feminine runs through the whole of Kogi life, not just their sexual mores. Thus you cannot build a bridge, a hut, a loom, or construct a path that winds through a village without the masculine/feminine principle being explicitly represented in some way" (See "Women in Kogi Society," http:/ / tairona.myzen.co.uk/index.php/culture/women_in_kogi_society). As with Irigaray, they see the technology of the western world as part of the death project because it is constructed without involving the generative principle of sexual difference and is therefore detached from life and meaningless: "The Kogi perceive life in many things which are in our understanding inanimate; any object which has meaning and purpose in the world...must be sustained by a balance of sexual forces, by its own Mother and Father" (Ereira above note 66 at 84).

${ }^{70}$ Ereira above note 66 at 92 . Because of the fundamentality of sexual difference to their culture, Ereira asked Gil about homosexuality to which he responded that although it is uncommon (and that he had never tried it), it is not considered unnatural and that there are even cases of homosexual marriage, including a story of two women who lived together as wives who were very insistent that sex between women is "far superior" (see Ereira above note 66 at 131-3).

${ }^{71}$ As Gil describes it, "The original laws, the fundamental principles, are in Sé....Sé is not a person, not a thing. It is the sum of things. Sé is complex...There are many different forms of existence; one is the material world that arose from $S e ́$ but there is much more that exists only in spirit....[Se] has no corporeal being - no body, no organs." The four axioms or principles of Sé (also referred to by Gil as "parents") are: the concept of order, the concept of materiality, the concept of time (memory, present, and possibility), and the concept of sexual difference. Ereira notes that the word "spirit" is misleading and that $S e ́$ could also be called "cosmic intelligence" (Gil as above note 66 at 21-4). 
the material world is an interconnected whole of nearly infinite complexity, but is embedded in a rational structure, the Kogi see it as absolutely mandatory—not to mention completely logical—that any thinking, and certainly any physical intervention, involve the incorporeal intelligence of the cosmos as a "partner" 72 In their view, then, while the science of the Younger Brother proclaims itself as the pinnacle of rational thinking, it is deeply limited and illogical because in attaining the stance of exteriority by which it surveys the world (especially through technological apparatuses), it has actually severed its direct thread to the sense of the cosmos and can therefore only infer this structure through the observation and calculation of visible effects within isolated regions of the physical world. ${ }^{73}$ They have recognized, however, that if their message is to be heeded, Younger Brother will need proof of what they are saying and thus they have recently met with a number of professional scientists, including astrophysicists, ecologists, marine biologists, and zoologists who have been stunned by their "cutting-edge" knowledge. For instance, they have demonstrated systematic understanding of some of the most complex and recent areas of western scientific research: regions of deep space impossible to observe without the most sophisticated telescopic instruments, the relativity of time and space, nonlocality, systems ecology, symbiogenesis, deep time, climate change, and, even "dark matter." This has been profound enough that the Colombian government hasalong with Spain, ironically_ sought their council on new environmental initiatives and practices.

\footnotetext{
${ }^{72}$ Gil as above note 66 at 23.

${ }^{73}$ Ereira writes that his occasional attempts to explain events in the news, such as debates about nuclear weapons, during his stays with the Kogi "were regarded as baffling and irrelevant. What difference does it make if we do not destroy the world in one way, when we are about to destroy it in another?" (178). Given the incredibly brief history of western technological science in comparison to their knowledge, they see our extreme pride in our science as short-sighted: "We are, to them, like people who have jumped off of a mountain and, falling fast, are proclaiming our ability to fly" (64). When speaking to the professional scientists in the film, the Mamas often seem extremely frustrated by the slow pace of our realizations, looking baffled when the scientists tell them about tentative research into and new "discoveries" of things they already know (esp. climate change and systems ecology). They think that our scientific burden of proof combined with our unwillingness to take any other knowledge practices seriously is endangering the entire planet.
} 
Heidegger, Irigaray, and the Kogi—each in their own way, no doubt—-thus pose serious and direct challenges to western science and technology regarding its complicity in the death project of western Man, challenges that should especially not be ignored by feminist theorists working to rethink the relationship between the humanities and sciences. Although, unlike Heidegger, the most important resonance between Irigaray's philosophy and the Kogi cosmology is their affirmation of life against the cosmic Being-toward-death of western metaphysics. To be sure, Heidegger's "preparatory thinking" was an indispensable contribution to the opening of a path beyond the GeStell of modern technological-scientific imperialism; however, his own forgetting of life meant that "thinking," for him, could never leave the shelter of the House of Language. With Irigaray and the Kogi, on the other hand, the walls of the ( $\mathrm{t}$ )autological circle of Being and thinking give way to a process of living in which perception and thinking are modes of participation in the life of the cosmos rather than the logical re-presentation, calculation, and ordering of a mechanical universe: a reciprocal (yet asymmetrical) partnership with the Mother as the Kogi describe it, or a sym-pathos or com-passion rather than an overcoming of mother-matter as Irigaray puts it. As the Being of Man hurtles to its "Ownmost possibility" (i.e., death writ large), we are faced with a life and death choice. ${ }^{74}$ This, of course, is something that colonized peoples have known all along, and as more and more people are realizing, it is perhaps to them that we must look for guidance in saving life itself. Such a project, no doubt, entails an enormous amount of ontological work on our part to even be able to comprehend such guidance. And yet this is an undertaking that we cannot afford not to take on. The Mother is dying, the Kogi are trying desperately to tell us. And she wants to know, they say, "whether we are going to help Her or just take pictures." 75 Within European thought it is Irigaray

\footnotetext{
${ }^{74}$ Heidegger famously calls death Dasein's "ownmost potentiality-of-being" in Being and Time (trans Joan Stambaugh) (The State University of New York Press 2007) 241.

${ }_{75}$ Aluna (directed by Alan Ereira, Sunstone Films, 2012)
} 
who has most ceaselessly tied the death project of Man to the originary and ongoing matricide that constitutes the metaphysics of technicity. And it is because of her raising of the profound questions about what kind of work with respect to sexuate difference we would have to do to end this matricide, let alone to actually recompense and assist the Mother, that in this essay I have placed Irigaray between god and the Indians. 